\title{
Bio- and toxic elements in edible wild mushrooms from two regions of potentially different environmental conditions in eastern Poland
}

\author{
Justyna Brzezicha-Cirocka $^{1}$ - Malgorzata Mędyk ${ }^{2} \cdot$ Jerzy Falandysz $^{2} \cdot$ Piotr Szefer $^{1}$
}

Received: 26 April 2016 / Accepted: 1 August 2016/Published online: 11 August 2016

(C) The Author(s) 2016. This article is published with open access at Springerlink.com

\begin{abstract}
In the present study, the composition of bioelements $(\mathrm{K}, \mathrm{Na}, \mathrm{Mg}, \mathrm{Ca}, \mathrm{Fe}, \mathrm{Cu}, \mathrm{Zn})$ and toxic elements $(\mathrm{Ag}, \mathrm{Cd})$ in seven edible mushrooms from the rural and woodland region of Morag (north-eastern Poland) and the rural and industrial region of the Tarnobrzeska Upland (south-eastern Poland) were investigated using a validated method. The species examined were Boletus edulis, Cantharellus cibarius, Leccinum aurantiacum, Leccinum versipelle, Lycoperdon perlatum, Suillus luteus, and Xerocomus subtomentosus. Final determination was carried out by flame atomic absorption spectroscopy (FAAS) after microwave-assisted decomposition of sample matrices with solutions of concentrated nitric acid in the pressurized polytetrafluoroethylene vessels. The contents of the alkali elements and alkali earth elements were determined in the species surveyed. The alkali elements, earth alkali elements, and transition metals $(\mathrm{Ag}, \mathrm{Cu}, \mathrm{Zn}, \mathrm{Fe}$, and $\mathrm{Mn}$ ) were at typical concentrations as was determined for the same or similar species elsewhere in Poland and Europe. The results may suggest a lack of local and regional emissions of those metallic elements from industrialization of some sites in the Tarnobrzeska Plain. Cadmium was at elevated concentrations in L. versipelle from the Tarnobrzeska Plain but the reason - pollution or geogenic source - was unknown, while it was at typical concentrations in other species.
\end{abstract}

Responsible editor: Philippe Garrigues

Jerzy Falandysz

jerzy.falandysz@ug.edu.pl

1 Department of Food Science, Gdańsk Medical University, 107 Gen. J. Haller Av, 80-416 Gdańsk, Poland

2 Laboratory of Environmental Chemistry and Ecotoxicology, Gdańsk University, 63 Wita Stwosza Str, 80-308 Gdańsk, Poland
Keywords Foraging $\cdot$ Forest $\cdot$ Mushrooms $\cdot$ Boletus . Cantharellus $\cdot$ Leccinum $\cdot$ Lycoperdon

\section{Introduction}

Wild-growing saprobic and symbiotic mushrooms may accumulate in their fruiting bodies' considerable amounts of metallic elements and metalloids due to specificities in their physiology (Aloupi et al. 2011; Frankowska et al. 2010; Kalač 2016). Mushrooms are relatively rich in mineral constituents, both edible and inedible or poisonous species which all are eaten by game animals (wild boars, stags, and others) and may end up in humans via the food chain (Brzostowski et al. 2011; Falandysz et al. 2007a, b, 2015). This is spectacularly evidenced for radiocesium $\left({ }^{137} \mathrm{Cs}\right)$, which is radiotoxic but also for typical toxic metals such as cadmium (Cd), lead $(\mathrm{Pb})$, mercury $(\mathrm{Hg})$, or silver $(\mathrm{Ag})$, which are well bioconcentrated from soil by many mushrooms (Borovička et al. 2010; Falandysz and Brzostowski, 2007; Malinowska et al. 2006; Solomko et al. 1986; Vinichuk et al. 2010).

Edible wild-growing mushrooms with an estimated number of 2000 species worldwide are a portion of a larger group of similar species (fungi forming fruit bodies in the form of mushrooms or similar shapes which are also called sporocarps) in the Kingdom of Fungi, and more studies are needed to characterize their mineral and other compound contents and compositions (Kalač 2016). An initial step in getting insight into mineral content and composition of edible mushrooms from the wild and their potential to accumulate minerals is the examination of crude (raw) fruiting bodies and the underneath substrate - soil or other (Falandysz et al. 2003, 2012; Garcia et al. 2009; Mleczek et al. 2013; Lu and Liang, 2014; Sarikurkcu et al. 2012). 
This study investigates the occurrence of metallic elements $(\mathrm{Ag}, \mathrm{Ca}, \mathrm{Cd}, \mathrm{Cu}, \mathrm{Fe}, \mathrm{Mg}, \mathrm{Na}, \mathrm{K}$, and $\mathrm{Zn}$ ) in fruiting bodies of seven species of mushrooms which are edible and can be foraged in Polish forests. Mushrooms were collected from two spatially distant forested areas in the north-east and south-east of Poland. The forested areas in the north-east are considered pristine when compared with other regions of the country. For example, the moss Pleurozium schreberi collected in 1975-1995 and 2010 from the north-east and north of Poland was significantly less affected by airborne $\mathrm{Cd}, \mathrm{Cr}, \mathrm{Cu}$, $\mathrm{Fe}, \mathrm{Ni}, \mathrm{Pb}$, and $\mathrm{Zn}$ than from other regions, while most polluted was from the south (Grodzińska et al. 1999; Kapusta et al. 2014).

\section{Materials and methods}

Fruit bodies of Boletus edulis Bull., Cantharellus cibarius Fr., Leccinum aurantiacum (Bull.) Gray, Leccinum versipelle (Fr. and Hök) Snell, Lycoperdon perlatum Pers., Suillus luteus (L.) Roussel, and Xerocomus subtomentosus L. were collected from the rural and woodland region near the town of Morag in north-eastern Poland and from the Tarnobrzeska Plain $\left(1411 \mathrm{~km}^{2}\right)$ in south-eastern Poland, which is in part an industrial region with rural and forested areas (remainders of the Sandomierska Primeval forest) (Fig. 1.). In the Tarnobrzeska Plain region, the steel mill Huta Stalowa Wola is located in the town of Stalowa Wola (founded in 1938) and also the opencast sulfur mine (also calcite, gypsum, quartz, aluminum oxide, celestine, and barite) in the Machów site (operated from 1964 to 1992) near the town of Tarnobrzeg.

Mushrooms (from 14 to 32 fruiting bodies per species) were cleaned from plant and soil debris, placed into plastic tray of an electrically heated commercial dryer, dried at $65^{\circ} \mathrm{C}$ to constant mass and further ground in porcelain mortars. The subsamples of powdered fungal materials were digested with

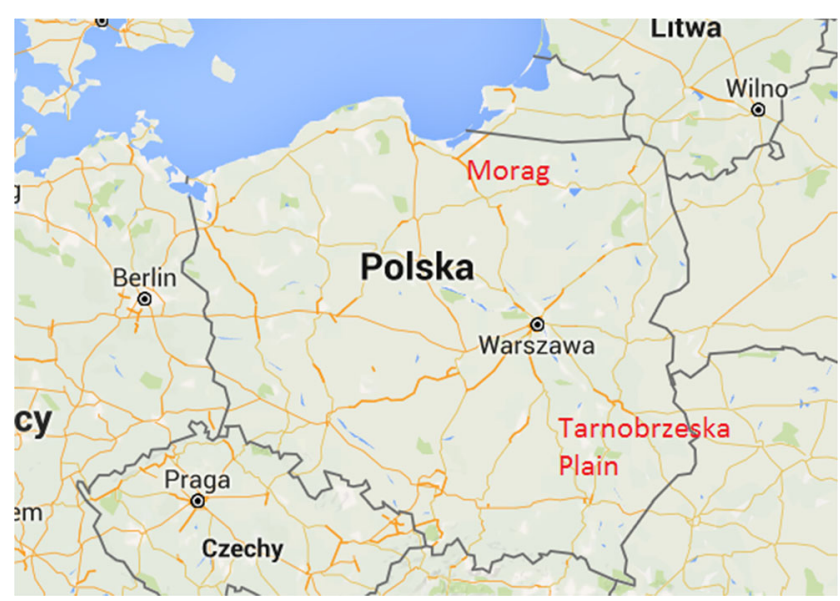

Fig. 1 Location of the sampling sites: Morag (coordinates 53 54' $5857^{\prime \prime}$ $\mathrm{N} 19^{\circ} 55^{\prime} 4025^{\prime \prime} \mathrm{E}$ ) and Tarnobrzeska Plain (coordinates 50 $50^{\circ} 5^{\prime} \mathrm{N} 21^{\circ} 41^{\prime}$ E) in Poland (Google maps; color figure available online) a solution of concentrated (65\%) nitric acid (Suprapur ${ }^{\circledR}$ Merck) in pressurized vessels made of polytetrafluoroethylene (PTFE) in an automatic microwave digestion system (MLS 1200). The metallic element concentrations were determined in an air-acetylene flame with the atomic absorption spectroscopy (AAS) method, using a background correction with a deuterium lamp. In order to determine the elements $\mathrm{K}$ and $\mathrm{Na}$, cesium (Cs) salt was added to the samples as an ionization buffer at a concentration of $0.2 \% \mathrm{w} / \mathrm{v}$, and for $\mathrm{Ca}$ and $\mathrm{Mg}$ measurements, lanthanum (La) salt was added at a concentration of $0.1 \% w / v$ as a releasing agent (Malinowska et al. 2004). Analytical control and analytical quality (AC/AQ) of determination were achieved by examination of procedural blanks and certified standard reference materials such as fish flour (SRM), lyophilized muscle tissue (MA-B-\#/TM), and sea lettuce (BCR-279 IRMM Ulva lactuca). The results obtained after examination of the reference materials were satisfactory (Table 1). The computer software Statistica version 10.0 (Statsoft Polska, Kraków, Poland) was used for statistical analysis of data.

\section{Results and discussion}

\section{Bio-elements}

Baseline data on concentrations of the macro- and trace metallic elements determined in the mushrooms from the Morag and Tarnobrzeska Plain sites are given in Table 1. The median values of the alkali element concentrations ranged from 27,000 to $47,000 \mathrm{mg} \mathrm{kg}^{-1}$ dry biomass (db) for potassium

Table 1 Results ( $\mathrm{mg} \mathrm{kg}^{-1}$ dry biomass) of the measurements of accuracy of the analytical data using certificate reference materials CRM 279 Ulva lactuca (sea lettuce), SRM (fish flour), and MA-B\#/TM (lyophilized muscle tissue)

\begin{tabular}{lclll}
\hline Element & Declared value & Own result & RSD (\%) & Recovery (\%) \\
\hline $\mathrm{Cd}^{\mathrm{a}}$ & $0.274 \pm 0.022$ & $0.232 \pm 0.024$ & 10.3 & 84.7 \\
$\mathrm{Cu}^{\mathrm{a}}$ & $13.14 \pm 0.37$ & $13.09 \pm 0.23$ & 1.65 & 99.6 \\
$\mathrm{~Pb}^{\mathrm{a}}$ & $13.48 \pm 0.36$ & $13.10 \pm 0.98$ & 7.48 & 97.2 \\
$\mathrm{Zn}^{\mathrm{a}}$ & $51.30 \pm 1.20$ & $50.24 \pm 1.59$ & 3.16 & 97.9 \\
$\mathrm{Hg}^{\mathrm{b}}$ & $0.21 \pm 0.02$ & $0.26 \pm 0.03$ & 11.5 & 123.8 \\
$\mathrm{Fe}^{\mathrm{c}}$ & 95.4 & $92.5 \pm 3.1$ & 3.37 & 97.0 \\
$\mathrm{Mn}^{\mathrm{c}}$ & 2.62 & $2.39 \pm 0.09$ & 3.76 & 91.2 \\
$\mathrm{Ca}^{\mathrm{c}}$ & 3490 & $3456 \pm 70$ & 2.02 & 99.0 \\
$\mathrm{Mg}^{\mathrm{c}}$ & 1130 & $1040 \pm 39$ & 3.71 & 92.0 \\
$\mathrm{Na}^{\mathrm{c}}$ & 2160 & $1776 \pm 53$ & 2.97 & 82.2 \\
$\mathrm{~K}^{\mathrm{c}}$ & 9320 & $9855 \pm 452$ & 4.59 & 105.7 \\
\hline
\end{tabular}

${ }^{\text {a }}$ CRM 279 Ulva lactuca (sea lettuce)

${ }^{\mathrm{b}}$ SRM (fish flour)

${ }^{\mathrm{c}}$ MA-B-\#/TM (lyophilized muscle tissue) 
and from 57 to $260 \mathrm{mg} \mathrm{kg}^{-1} \mathrm{db}$ for sodium. Hence, mushrooms foraged from the forests nearby to Morag and from the Tarnobrzeska Plain, like many other mycorrhizal species collected in the wild from unpolluted areas, can be considered as a component of a diet that is rich in potassium and low in sodium.

Mushrooms as foodstuff can be a good source of minerals for human nutrition. However, minerals may leach out of the flesh of cooked mushrooms, e.g., into a liquid phase, when mushrooms are boiled at a short time (blanched), and the liquid is discarded. Without a doubt, all inorganic constituents well soluble in water will highly diminish in blanched mushrooms but the same will happen to some toxic elements, e.g., radiocesium. Another question is the bioavailability of minerals from mushrooms in the alimentary tract of man, which is a little-known process. It can be anticipated that mineral constituents easily leach out during blanching of fresh/frozen or cold soaking (macerating) of dried mushrooms, e.g., alkaline elements. In the absence of blanching or soaking, minerals in mushroom meals may be well bioavailable.

B. edulis from both sites showed in whole fruiting bodies similar concentrations of potassium - median values respectively at 27,000 and $31,000 \mathrm{mg} \mathrm{kg}^{-1} \mathrm{db}$ (Table 2), which is consistent with data reported for caps and stipes of this species collected from other locations in Poland (Frankowska et al. 2010). In L. perlatum, potassium was at $28,000 \mathrm{mg} \mathrm{kg}^{-1} \mathrm{db}$ which was similar to B. edulis. Both $C$. cibarius with potassium at $47,000 \mathrm{mg} \mathrm{kg}^{-1} \mathrm{db}$ and $X$. subtomentosus with $46,000 \mathrm{mg} \mathrm{kg}^{-1} \mathrm{db}$ in caps and 44,000 $\mathrm{mg} \mathrm{kg}^{-1} \mathrm{db}$ in stipes in this study can be considered as richer in this element than B. edulis and L. perlatum. Those data on potassium in $C$. cibarius and $X$. subtomentosus agreed with results from other studies (Falandysz and Drewnowska, 2015; Jarzyńska et al. 2012). The mushrooms of the genus Leccinum such as $L$. aurantiacum and $L$. versipelle were rich and similar in the content of potassium, which was, respectively, at 33,000 and $36,000 \mathrm{mg} \mathrm{kg}^{-1} \mathrm{db}$ (median values). Those concentrations of potassium are consistent with the content in other Leccinum spp., e.g., L. scabrum (Bull.) gray (range of medians for caps at 34,000-52,000 $\mathrm{mg} \mathrm{kg}^{-1} \mathrm{db}$ ) and L. duriusculum (Schulzer ex Kalchbr.) singer (median at $37,000 \mathrm{mg} \mathrm{kg}^{-1} \mathrm{db}$ ) (Falandysz et al. 2007c; Jarzyńska and Falandysz, 2012a). Potassium content in S. luteus with a median value in caps at $34,000 \mathrm{mg} \mathrm{kg}^{-1} \mathrm{db}$ and in stipes at $35,000 \mathrm{mg} \mathrm{kg}^{-1} \mathrm{db}$ was consistent with the median values for $S$. grevillei (range $27,000-40,000 \mathrm{mg} \mathrm{kg}^{-1} \mathrm{db}$ for caps and 21,000-38,000 mg kg-1 $\mathrm{db}$ for stipes) (Chudzyński and Falandysz 2008). In view of the results obtained for potassium and in consideration of the literature data for the same species or genus, the industrialization of the Tarnobrzeska Plain was without an impact on the potassium content of mushrooms from the wild in this location.
Mushrooms are considered as a foodstuff very low in sodium (Vetter, 2003). In this study, the median values of sodium in a particular mushroom species or their morphological parts were below $300 \mathrm{mg} \mathrm{kg}^{-1} \mathrm{db}$, which is consistent with data reviewed recently for several species (Falandysz and Borovička, 2013).

Median values of magnesium and calcium, the alkali earth elements investigated in this study, were at a range of 810-1900 $\mathrm{mg} \mathrm{kg}^{-1} \mathrm{db}(\mathrm{Mg})$ and $120-1000 \mathrm{mg} \mathrm{kg}^{-1} \mathrm{db}(\mathrm{Ca})$ (Table 2). They are both elements essential for biota, but mushrooms are usually substantially lower in calcium than in magnesium content (Falandysz and Borovička, 2013). The discrepancies in the median values of magnesium concentrations were negligible between the capped mushrooms, while the flesh of $L$. perlatum was more rich in this element and showing the maximum value mentioned earlier. Mushrooms in this study differed highly in concentrations of calcium concerning both different species but also individuals of the same species or species from the same genus as well as the morphological parts of fruit bodies (Table 2). Calcium as well as sodium, barium, and strontium occurred at greater concentrations in stipes than in caps of mature mushrooms (Falandysz and Borovička, 2013).

The transition metals such as $\mathrm{Cu}, \mathrm{Zn}, \mathrm{Fe}$, and $\mathrm{Mn}$ are important cofactors in the enzymes of biota. A mushroom that is exceptionally rich in iron is Suillus variegatus (Sw.) Richon and Roze, with iron concentrations reported at a range of 3300-4100 mg kg-1 $\mathrm{db}$ (Falandysz et al. 2001). The range of the median values for iron in mushrooms surveyed was at $35-460 \mathrm{mg} \mathrm{kg}^{-1} \mathrm{db}$.

Mushrooms collected from the wild are usually rich in copper and zinc both of which are physiologically essential, while their concentrations differ for the species (Falandysz and Borovička, 2013). L. perlatum was richer both in $\mathrm{Cu}$ and $\mathrm{Zn}$ than other species examined, and the median values of their concentrations in caps or whole fruiting bodies were, respectively, at 100 and $16-52 \mathrm{mg} \mathrm{kg}^{-1} \mathrm{db}$ for $\mathrm{Cu}$, and at 200 and $80-190 \mathrm{mg} \mathrm{kg}^{-1} \mathrm{db}$ for $\mathrm{Zn}$. Stipes of $S$. luteus were much lower in $\mathrm{Cu}$ and $\mathrm{Zn}$ than caps ( $p<0.05$; Man-Whitney $\mathrm{U}$ test). Mushrooms of the genus Boletus are lower in copper than those of the genus Agaricus or Macrolepiota ((Alonso et al. 2003; Gucia et al. 2012a, b; Jorhem and Sundström, 1995; Mleczek et al. 2015). Copper in C. cibarius collected (median at $52 \mathrm{mg} \mathrm{kg}^{-1} \mathrm{db}$ ) and also zinc (median at $80 \mathrm{mg} \mathrm{kg}^{-1} \mathrm{db}$ ) were in typical concentrations for this species. For example, copper in C. cibarius from Spain was reported at $53-70 \mathrm{mg} \mathrm{kg}^{-1}$ $\mathrm{db}$ and from Sweden at $46 \mathrm{mg} \mathrm{kg}^{-1} \mathrm{db}$, while zinc, respectively, at $71-100$ and at $110 \mathrm{mg} \mathrm{kg}^{-1} \mathrm{db}$ (Alonso et al. 2003; Jorhem and Sundström, 1995).

$S$. luteus and L. perlatum showed manganese in fruiting bodies at $35-46 \mathrm{mg} \mathrm{kg}^{-1} \mathrm{db}$, and they were substantially richer in this element than other species in this study for which medians ranged from 8.6 to $27 \mathrm{mg} \mathrm{kg}^{-1} \mathrm{db}(p<0.05$; Man- 


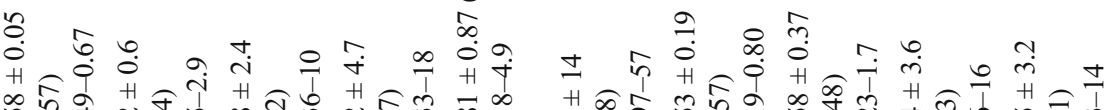

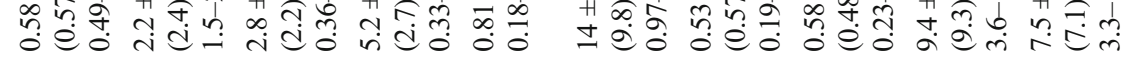

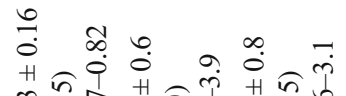

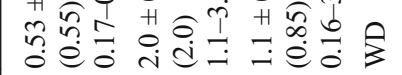

$\stackrel{3}{0} \dot{m}$

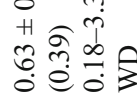

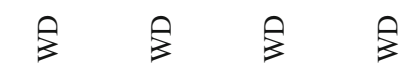

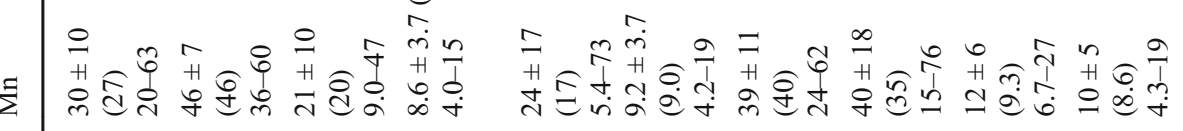
○ ఠิ

茾

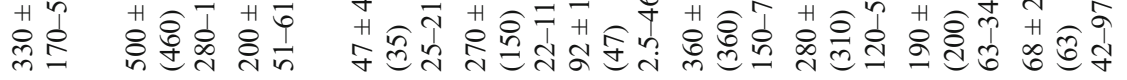

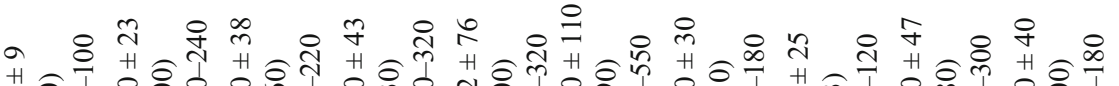

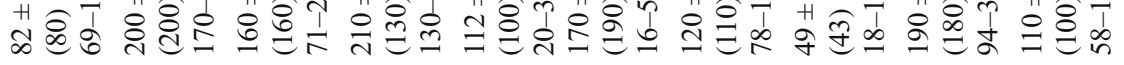

छे

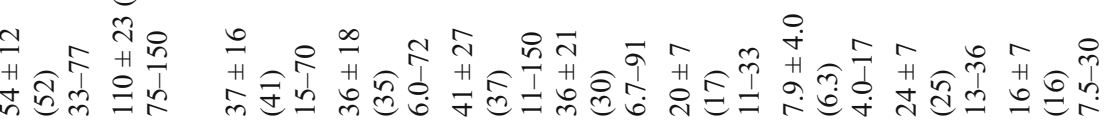
芹 \& 8 :

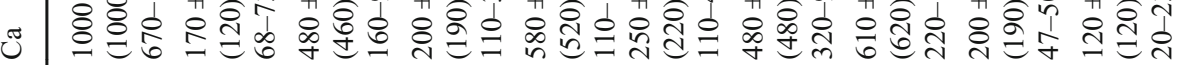
○. 0 \& 8 \&

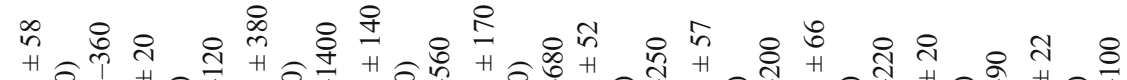

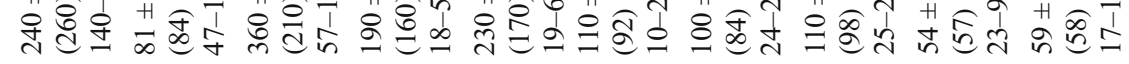

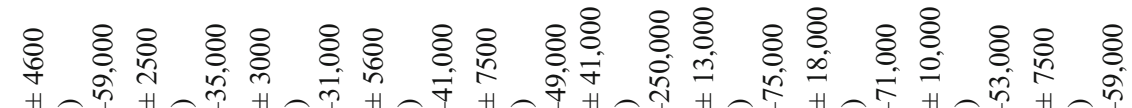

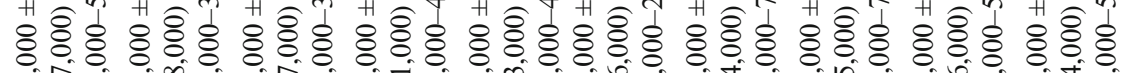

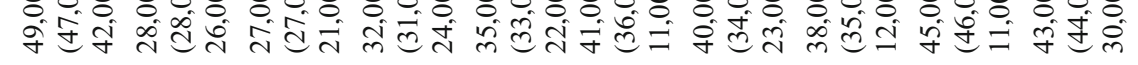


Whitney U test). Both the earth alkali elements and the transition metals ( $\mathrm{Cu}, \mathrm{Zn}, \mathrm{Fe}$, and $\mathrm{Mn}$ ) in mushrooms were found at concentrations similar to those for the same or similar species elsewhere in Europe. The results may suggest a lack of local and regional emissions of those metallic elements from industrialization of some sites in the Tarnobrzeska Plain.

\section{Toxic elements}

The toxic cadmium and silver determined in mushrooms in this study are both chalcophile elements, while the silver $\left(\mathrm{Ag}^{+}\right)$ion is highly proteotoxic. All specimens examined showed cadmium at a detectable concentration, while $X$. subtomentosus, L. versipelle, and B. edulis were substantially richer in this element than other species (Table 2). C. cibarius, L. aurantiacum, and S. luteus can be considered as low in cadmium (medians $<1.0 \mathrm{mg} \mathrm{kg}^{-1} \mathrm{db}$ ). Exceptionally high in cadmium was $L$. versipelle from the Tarnobrzeska Plain for which the median value in whole fruiting bodies was at $9.8 \mathrm{mg} \mathrm{kg}^{-1} \mathrm{db}$. Currently, there is a lack of credible data on cadmium in L. versipelle from other regions of Poland, and it cannot be determined whether the measured cadmium values are geogenic or largely anthropogenic. Mercury in L. versipelle from the Tarnobrzeska Plain was at a similar concentration for this element to sites considered as uncontaminated from local or regional emission sources (Falandysz, 2002; Krasińska and Falandysz, 2016).

Leccinum scabrum sampled from the background (unpolluted) areas of Poland contained cadmium in caps at 2.4 to $5.7 \mathrm{mg} \mathrm{kg}^{-1} \mathrm{db}$ (medians) (Falandysz et al. 2007c). Cadmium in Leccinum griseum (Quél.) Bresinsky \& Manfr. Binder from a single site sampled in Poland was at $3.3 \mathrm{mg} \mathrm{kg}^{-1}$ $\mathrm{db}$ (median) in caps and at $1.2 \mathrm{mg} \mathrm{kg}^{-1} \mathrm{db}$ (median) in stipes, and in L. duriusculum, respectively, at $1.3 \mathrm{db}$ and $0.45 \mathrm{mg} \mathrm{kg}^{-1}$ db (Jarzyńska and Falandysz, 2012a, b). In light of those data on cadmium content of mushrooms of the genus Leccinum, the concentration recorded for $L$. versipelle from the Tarnobrzeska Plain seemed elevated, but more results from this region are needed to assess its possible anthropogenic origin or whether other factors are involved.

Cadmium and silver were at similar concentrations in C. cibarius, L. perlatum, and L. aurantiacum but silver was less abundant in B. edulis (Table 2). Silver and cadmium are efficiently accumulated from soil and other substrata by different mushrooms but fewer data are available on silver and a possible risk from this element in edible mushrooms and other foods than for cadmium (Byrne and Tušek-Žnidarič, 1990; Falandysz and Danisiewicz, 1995; Falandysz et al., 1994).

The maximum permissible concentration for cadmium in edible mushrooms set in the European Union is $0.2 \mathrm{mg} \mathrm{kg}^{-1}$ fresh product for three cultivated species such as Agaricus bisporus (J. E. Lange) Imbach, (common mushroom), Pleurotus ostreatus ((Jacq.) P. Kumm. (oyster mushroom), and Lentinula edodes (Berk.) Pegler (shiitake mushroom), and for other mushrooms, it is $1.0 \mathrm{mg} \mathrm{kg}^{-1}$ fresh product (Commission Regulation, 2008). There is a consensus that the moisture content of fresh mushrooms is at $90 \%$. The cited tolerance value for cadmium in mushrooms when expressed on a dry biomass basis is $2.0 \mathrm{mg} \mathrm{kg}^{-1}$ for cultivated species and $10 \mathrm{mg} \mathrm{kg}^{-1}$ for other mushrooms. In a light of those values, only $L$. versipelle from the Tarnobrzeska Plain showed cadmium in whole fruiting bodies at median concentrations close to the maximum value tolerated, while in other species, cadmium was much below this value.

\section{Conclusions}

The alkali elements ( $\mathrm{K}, \mathrm{Na})$, alkali earth elements $(\mathrm{Ca}, \mathrm{Mg})$, and transition metals ( $\mathrm{Ag}, \mathrm{Cu}, \mathrm{Zn}, \mathrm{Fe}$, and $\mathrm{Mn}$ ) in mushrooms were at concentrations similar to those determined for the same or similar species elsewhere in Poland and Europe. The results may suggest a lack of local and regional emissions of those metallic elements from industrialization of some sites in the Tarnobrzeska Plain. Cadmium was at elevated concentrations in L. versipelle from the Tarnobrzeska Plain but the reason - pollution or geogenic source-was unknown, while cadmium was at typical concentrations in other species.

Acknowledgments Critical comment to this manuscript by Professor Roland Treu (Athabasca University) is acknowledged.

Open Access This article is distributed under the terms of the Creative Commons Attribution 4.0 International License (http:// creativecommons.org/licenses/by/4.0/), which permits unrestricted use, distribution, and reproduction in any medium, provided you give appropriate credit to the original author(s) and the source, provide a link to the Creative Commons license, and indicate if changes were made.

\section{References}

Alonso J, García MA, Peréz-López M, Melgar JM (2003) The concentrations and bioconcentration factors of copper and zinc in edible mushrooms. Arch Environ Contam Toxicol 44:180-188

Aloupi M, Koutrotsios G, Koulousaris M, Kalogeropoulos N (2011) Trace metal contents in wild edible mushrooms growing on serpentine and volcanic soils on the island of Lesvos, Greece. Ecotox Environ Safe 78:184-194

Borovička J, Kotrba P, Gryndler M, Mihaljevič M, Řanda Z, Rohovec J, Cajthaml T, Stijve T, Dunn CE (2010) Bioaccumulation of silver in ectomycorrhizal and saprobic macrofungi from pristine and polluted areas. Sci Total Environ 408:2733-2744

Brzostowski A, Jarzyńska G, Kojta AK, Wydmańska D (2011) Variations in metal levels accumulated in Poison Pax (Paxillus involutus) mushroom collected at one site over four years. J Environ Sci Health Part A 46:581-588 
Byrne AR, Tušek-Žnidarič M (1990) Studies of the uptake and binding of trace metals in fungi. Part I: accumulation and characterization of mercury and silver in the cultivated mushroom Agaricus bisporus. Appl Organomet Chem 4:43-48

Chudzyński K, Falandysz J (2008) Multivariate analysis of elements content of Larch Bolete (Suillus grevillei) mushroom. Chemosphere 78:1230-1239

Commission Regulation (2008) (EC) No. 629/2008 of 2 July 2008 amending Regulation (EC) No. 1881/2006 setting maximum levels for certain contaminants in foodstuffs. Official Journal of the European Union 173, 6

Falandysz J (2002) Mercury in mushrooms and soil of the Tarnobrzeska Plain, south-eastern Poland. J Environ Sci Health Part A 37:343352

Falandysz J, Borovička J (2013) Macro and trace mineral constituents and radionuclides in mushrooms: health benefits and risks. Appl Microbiol Biotechnol 97:477-501

Falandysz J, Brzostowski A (2007) Mercury and its bioconcentration factors in Poison Pax (Paxillus involutus) from various sites in Poland. J Environ Sci Health Part A 42:1095-1100

Falandysz J, Danisiewicz D (1995) Bioconcentration factors (BCF) of silver in wild Agaricus campestris. Bull Environ Contam Toxicol 55:122-129

Falandysz J, Drewnowska M (2015) Macro and trace elements in Common Chanterelle (Cantharellus cibarius) mushroom from the European background areas in Poland: Composition, accumulation, dietary exposure and data review for species. J Environ Sci Health Part B 50:374-387

Falandysz J, Bona H, Danisiewicz D (1994) Silver content of wild-grown mushrooms from northern Poland. Zeitschr Lebensm- Unters Forsch 199:222-224

Falandysz J, Szymczyk K, Ichihashi H, Bielawski L, Gucia M, Frankowska A, Yamasaki S (2001) ICP/MS and ICP/AES elemental analysis (38 elements) of edible wild mushrooms growing in Poland. Food Addit Contam 18:503-513

Falandysz J, Brzostowski A, Kawano M, Kannan K, Puzyn T, Lipka K (2003) Concentrations of mercury in wild growing higher fungi and underlying substrate near lake Wdzydze, Poland. Water Air Soil Poll 148:127-137

Falandysz J, Kunito T, Kubota R, Brzostowski A, Mazur A, Falandysz JJ, Tanabe S (2007a) Selected elements of Poison Pax Paxillus involutus. J Environ Sci Health Part A 42:1161-1169

Falandysz J, Kunito T, Kubota R, Lipka K, Mazur A, JJ F, Tanabe S (2007b) Selected elements in Fly Agaric Amanita muscaria. J Environ Sci Health Part A 42:1615-1623

Falandysz J, Kunito T, Kubota R, Bielawski L, Mazur A, Falandysz JJ, Tanabe S (2007c) Selected elements in Brown Birch Scaber Stalk Leccinum scabrum. J Environ Sci Health Part A 42:2081-2088

Falandysz J, Widzicka E, Kojta AK, Jarzyńska G, Drewnowska M, Danisiewicz-Czupryńska D, Dryżałowska A, Lenz E, Nnorom IC (2012) Mercury in Common Chanterelles mushrooms: Cantharellus spp. update. Food Chem 133:842-850

Falandysz J, Zhang J, Wang Y, Krasińska G, Kojta A, Saba M, Shen T, Li T, Liu H (2015) Evaluation of the mercury contamination in mushrooms of genus Leccinum from two different regions of the world: accumulation, distribution and probable dietary intake. Sci Total Environ 537:470-478

Frankowska A, Ziółkowska J, Bielawski L, Falandysz J (2010) Profile and bioconcentration of minerals by King Bolete (Boletes edulis) from the Płocka Dale in Poland. Food Addit Contam B 3:1-6

García MA, Alonso J, Melgar MJ (2009) Lead in edible mushrooms levels and bioaccumulation factors. J Hazard Mater 167:777-783
Grodzińska K, Szarek-Łukaszewska G, Godzik B (1999) Survey of heavy metal deposition in Poland using mosses as indicators. Sci Total Environ 229:41-51

Gucia M, Kojta AK, Jarzyńska G, Rafał E, Roszak M, Osiej I, Falandysz J (2012a) Multivariate analysis of mineral constituents of edible Parasol Mushroom (Macrolepiota procera) and soils beneath fruiting bodies collected from northern Poland. Environ Sci Poll Res 19:416-431

Gucia M, Jarzyńska G, Kojta AK (2012b) Temporal variability in twenty chemical elements content of Parasol Mushroom (Macrolepiota procera) collected from two sites over a few years. J Environ Sci Health Part B 47:81-88

Jarzyńska G, Falandysz J (2012a) Metallic elements profile of Slate Bolete (Leccinum duriusculum) mushroom and associated soil horizon. J Geochem Expl 121:69-75

Jarzyńska G, Falandysz J (2012b) Metallic elements profile of Hazel (Hard) Bolete (Leccinum griseum) mushroom and associated upper soil horizon. African J Biotechnol 11:4588-4594

Jarzyńska G, Chojnacka A, Dryżałowska A, Nnorom IC, Falandysz J (2012) Concentrations and bioconcentration factors of minerals by yellow-cracking Bolete (Xerocomus subtomentosus) mushroom collected in Noteć Forest, Poland. J Food Sci 77:H202-H206

Jorhem L, Sundström B (1995) Levels of some trace elements in edible fungi. Zeitschr Lebensm- Unters -Forsch 201:311-316

Kalač P (2016) Edible mushrooms, chemical composition and nutritional value. Academic Press, London

Kapusta P, Szarek-Łukaszewska G, Godzik B (2014) Present and past deposition of heavy metals in Poland as determined by moss monitoring. Pol J Environ Stud 23:2047-2053

Krasińska G, Falandysz J (2016) Mercury in Orange Birch Bolete Leccinum versipelle and soil substratum: bio-concentration by mushroom and probable dietary intake by consumers. Environ Sci Poll Res 23:860-869

Lu J-F, Liang C-Z (2014) Risk assessment of heavy metal pollution in edible fungi in Zhejiang province. J Beijing Univ Agric 29:33-37

Malinowska E, Szefer P, Falandysz J (2004) Metals bioaccumulation by bay bolete, Xerocomus badius, from selected sites in Poland. Food Chem 84:405-416

Malinowska E, Szefer P, Bojanowski R (2006) Radionuclides content in Xerocomus badius and the other commercial mushrooms from several regions of Poland. Food Chem 97:19-24

Mleczek M, Magdziak Z, Goliński P, Siwulski M, Stuper-Szablewska K (2013) Concentrations of minerals in selected edible mushroom species growing in Poland and their effect on human health. Acta Sci Pol Technol Aliment 12:203-214

Mleczek M, Siwulski M, Mikołajczak P, Gasecka M, Rissmann I, Goliński P, Sobieralski K (2015) Differences in $\mathrm{Cu}$ content in selected mushroom species growing in the same unpolluted areas in Poland. J Environ Sci Health Part B 50:659-666

Sarikurkcu C, Tepe B, Solak MH, Cetinkaya S (2012) Metal concentrations of wild edible mushrooms from Turkey. Ecol Food Nutr 51: 346-363

Solomko EF, Grodzinskaya AA, Paschenko LA, Pchelintseva RK (1986) Mineralnij szosztav nekotorih kultivirujemih i dikorasztusih gribov klassa Basidiomycetes. (Mineral composition of some cultivated and wild fungi of the class Basidiomycetes). Mikologia i fitopatologii 20:474-478

Vetter J (2003) Data on sodium content of common edible mushrooms. Food Chem 81:589-593

Vinichuk M, Taylor AFS, Rosén K, Johanson KJ (2010) Accumulation of potassium, rubidium and caesium $\left({ }^{133} \mathrm{Cs}\right.$ and $\left.{ }^{137} \mathrm{Cs}\right)$ in various fractions of soils and fungi in a Swedish forest. Sci Total Environ 408: 2543-2548 